ACTA MYCOLOGICA

Vol. 42 (1): 75-78

2007
Dedicated to Professor Alina Skirgietto

on the occasion of her ninety-fifth birthday

\title{
Xylaria oxyacanthae Tul. et C. Tul., a new species for Poland
}

\author{
ANNA KUJAWA ${ }^{1}$ and DARIUSZ KARASIŃSKI ${ }^{2}$ \\ ${ }^{1}$ Field Station of Research Center for Agricultural and Forest Environment Polish Academy of Sciences \\ Turew, Szkolna 4, PL-64-000 Kościan, annakuja@poczta.onet.pl \\ ${ }^{2}$ Staromostowa 4/8, PL-30-506 Kraków, darek_karasinski@op.pl
}

Kujawa A., Karasiński D.: Xylaria oxyacanthae Tul. et C. Tul., a new species for Poland. Acta Mycol. 42 (1):75-78, 2007.

The paper presents information about Xylaria oxyacanthae Tul. \& C. Tul., a new species for Poland. The fungus was for the first time found in the mid-field shelterbelt near Turew village and in the city park in Kraków.

Key words: Ascomycetes, Xylariales, macrofungi, Xylaria oxyacanthae, distribution, Poland

\section{INTRODUCTION}

Xylaria oxyacanthae Tul. et C. Tul. belongs to Xylariales (Kirk et al. 2001). For the first time it was described in 1863 from France. The species, grows on mummified fruits of Crataegus monogyna therefore its distribution is closely related to occurrence of the species. In Europe is rarely seen, among others in England (Minter 1986), Netherlands (Bas 1981; Reynders 1983), Czech Republic (Antonín, Vagner 1998), Germany (Krieglsteiner 1983, 1993; Hettich, Beenken 1997), Denmark (Læssøe 1994; Whalley 2000), Belgium (De Meulder 1984) and France (Tulasne, Tulasne 1863; Le roy, Surault 1995). There are also some localities found in North America (Stowell, Rogers 1983).

Unlike neighboring Germany and Czech Republic (as mentioned above) in Poland the species has never been recorded before.

\section{DESCRIPTION OF THE SPECIES MORPHOLOGY}

Like other species of the genus, Xylaria oxyacanthae passes through two stages anamorphic and teleomorphic one. The development of stromata begins in spring. The stromata develop on fallen and usually buried fruits of hawthorn that were produced in the year before. In summer, conidiophores with conidia develop on stromata (Figs 1b, 1c; 2a). During the late summer and autumn the same stromata form 
the basis for perithecia and those, when mature, produce the ascospores (Figs 1a; 2c). The stromata die out during the late autumn.

The macro- and microscopic features of $X$. oxyacanthae have been described by many authors (Tulasne, Tulasne 1863; Bas 1981; Stowell, Rogers 1983; Hettich, Beenken 1997; Antonín, Vagner 1998).

MACROSCOPIC FEATURES. Stromata which grow up from mummified fruits of hawthorn are slender, simple or branched, 10-60 mm long and 1-4 mm thick, cylindrical, lightly laterally compressed. In conidial stage conidiophores develop on upper part of stromata and produce conidia which cover stromata with white layer. Apices yellowish to pink, remain sterile. Lower parts of stromata remain black and sterile too (Figs 1b, 1c; 2a). During anamorphic stage stromata grow thicker (3-4mm), and globose or subglobose perithecia $(0.3-0.5 \mathrm{~mm}$ in diameter) submersed in stromata become visible. In this period stromata are easy to be overlooked as they become black and their brighter apices often come away (Figs 1a; $2 \mathrm{c}$ ). The lower parts of stromata are covered in the soil. The hawthorn fruits they grow upwards from are sometimes join together by very thin filaments of hyphae.

Microscopic features. Conidia globose to ovoid, uncoloured, 3.1-4.3 x 2.4-3.8 $\mu \mathrm{m}$. Asci 8-spored, cylindrical. According to Bas (1981) size of asci amounts 78-94 x 4.5$8.5 \mu \mathrm{m}$, but according to other authors (Stowe1l, Rogers 1983; Hettich, Beenken 1997; Antonín, Vagner 1998) they could be somewhat bigger: 100-140 x 6-9 $\mu \mathrm{m}$. Apical apparatus cylindrical, iodine positive. Paraphyses filamentous, lucid.

Ascospores inaequilaterally elliptic to navicular, dark brown to black, with straight germ slit running almost trough the full length of the spore (8) 10-13 (14) $\mathrm{x}$ 4.5-6.0 $\mu \mathrm{m}$.

Macro- and microscopic features of $X$. oxyacanthae found in Poland do not differ from those described in bibliography. The size of asci amounts to $120-135 \times 6-8 \mu \mathrm{m}$ and fit the range given by most of other authors.

\section{CHARACTERISTIC OF THE LOCALITIES}

For the first time $X$. oxyacanthae was found in Poland on $5^{\text {th }}$ of July 2001 during the long term research on macromycetes of the General Dezydery Chłapowski Landscape Park (Fig. 1). About 300 of anamorphic stromata growing on mummified hawthorn fruits were discovered in a midfield shelterbelt near Turew (ATPOL BD 48-00). The plant community composition of this afforestation is similar to riparian forest Populetum albae.

The canopy is dominated by Populus alba, the shrub layer by Crataegus monogyna with some admixture of Cornus sanguinea and Sambucus nigra. The herb layer is formed by mesophilous species from Querco-Fagetea class, such as Aegopodium podagraria, Brachypodium sylvaticum, Ficaria verna, Festuca gigantea, Ranunculus lanuginosus, Stachys sylvatica. The representatives of nitrophilous species from Artemisietea vulgaris class are also present: Alliaria petiolata, Galium aparine, Geum urbanum and Urtica dioica.

During the few consecutive years of research following numbers of $X$. oxyacanthae stromata were recorded on the site: in $2002-300$, in $2003-5$, in $2004-200$, and in $2005-600$. The hawthorn is a quite common species in the Landscape Park, 
but in spite of very careful search no other localities of the fungus were found in the area.

The second Polish locality of Xylaria oxyacanthae was discovered on $21^{\text {th }}$ of June 2004 in a city park called „Skały Twardowskiego” in Krakow (ATPOL DF-69). The anamorphic stromata of the fungus were found at the park edge close to Tyniecka street, some $30 \mathrm{~m}$ away from the bank of Vistula river (Fig. 2). The site is impure by strollers and presumably no intensive green-keeping works have recently been carried out there, a part from periodical shrubs trimming along the footpath. The tree stand is diverse with predomination of Fraxinus excelsior and Acer platanoides, and some admixture of Acer negundo, Betula pubescens, Malus domestica, Juglans regia, Prunus avium, Robinia pseudacacia and Tilia cordata. Shrub layer is well developed, with predomination of Crataegus monogyna, Sambucus nigra and undergrowth of Acer platanoides, A. negundo and Fraxinus excelsior, additionally enriched by Philadelphus coronarius. Despite of deep shade, herb layer is very abundant covering $80 \%$ of the plot. Nitrophilous species from the Artemisietea vulgaris class such as Chelidonium majus, Urtica dioica, Geum urbanum, Galium aparine, Alliaria petiolata and Viola odorata are most frequent. Woodland species from the Querco-Fagetea class have also significant share, especially Ficaria verna and Aegopodium podagraria.

Stromata of Xylaria oxyacanthae grew on the verge of shallow depression under one of the several hawthorns. Altogether 50 differently developed specimens (the biggest one was $27 \mathrm{~mm}$ tall) were found on the area of $2 \mathrm{~m}^{2}$. Most of the stromata were rachitic and gracile, and only in few cases branched. The fruits of Crataegus monogyna colonized by Xylaria oxyacanthae were most often buried several $\mathrm{cm}$ under the ground and linked to stromata by thin, black filaments of hyphae. In several cases the filaments growing upwards from two or three mummified fruits were joined together to form single stromatum. Only in few cases the stromata grew upwards from the fruits that were not fully buried in the substrate.

One-half of the stromata was collected and the rest was left, but despite of intensive search no teleomorphic forms of stromata were found in autumn.

In the spring 2005 , on $17^{\text {th }}$ of May, a dozen or so of new stromata were found exactly in the same place. During the next few visits it was observed that the stromata have gradually disappeared, as the result of intensive feeding of arthropods from the Armadilidium vulgare species (Fig. 2b), which occurred in masses.

\section{REMARKS}

Some authors suggest that the species is not as rare as it could be inferred from only few localities found, because, as they underline, due to small size, dark colour of stromata and specific environmental requirements the species is easy to be overlooked (Minter 1986, Læssøe 1994). Other authors (Whalley 1987; Leroy, Surault 1995) stress, that first of all, the specific habitat demands are the reason for rare occurrence of the species, as its distribution is absolutely dependent on buried hawthorn fruits presence. Studies carried out in France (Le roy, S u r a ult 1995) and Germany (Krieglsteiner 1993; Hettich, Beenken 1997) showed that the occurrence of hawthorn per se is insufficient for $X$. oxyacantha occurence.

Additional conditions favorable for $X$. oxyacantha presence are either the thick layer of litter deposition, that can cover hawthorn fruits, or the presence of soil 
cracks into which the fruits can fall, because the fungus stromata most often grow from the fruits buried shallow under the ground surface (Bas 1981; Reynders 1983; Leroy, Surault 1995). The other interesting feature characteristic for the species ecology are the numerous stromata which sometimes occur in as many as hundred per one $\mathrm{m}^{2}$ (Reynders 1983; De Meulder 1984; Heittich, Beenken 1997).

Acknowledgements. We thank conservators of herbaria: KRA, KRAM, KTCB, LBL, LOD, POZM, SZCZ, SZUB, TRN, WA, WRSL for their kind help in gathering information about the species as well as Dr. Anna Ronikier, M. Sc. Marek Halama and M. Sc. Wojciech Pusz for their kind help with completing of bibliography and Dr. Krzysztof Kujawa for making the photographs. We also thank anonymous reviewer of our paper.

\section{REFERENCES}

Antonín V., Vagner A. 1998. New, rare and less known macromycetes in Moravia (Czech Republic) - IV. Acta Mus. Moraviae. Sci. Biol. 82: 29-38.

B a s C. 1981. Een nieuve Xylaria voor ons land. Coolia 24 (1): 7-10.

De Meulder H. 1984. Xylaria oxyacanthae Tul., nieuw voor de Belgische fungiflora. Antwerpse Mykologiske Kring, Mededelingen 84 (2): 33-35.

Hettich F., Beenken L. 1997. Xylaria oxyacanthae Tul. \& Tul., die „Weißdornbeeren-Holzkeule”, erstmals in Bayern nachgewiesen. Mycologia Bavarica 2: 61-64.

Kirk M. P., Can n on P. F., David J. C. \& Stalpers J. A. (eds). 2001. Ainsworth and Bisby's dictionary of fungi. 9-ed. CAB. International, Wallinford, ss.xi +655 .

Krieglsteiner G. J. 1983. Über neue, seltene, kritische Makromyzeten in der Bundesrepublik Deutschland. Z. Mykol. 49 (1): 73-106.

Kri e gls t e in e r G. J. 1993. Verbreitungsatlas der Großpilze Deutschlands (West). Bd.II: Schlauchpilze. Stuttgart.

Læs s øe T. 1994. Hvor almindelig er Tjørne-Stødsvamp?. Svampe 30: 55.

Le roy P., Surault J-P. 1995. Xylaria oxyacanthae Tulasne 1863. Observation sur plusieurs mois d'une espèce rarement décrite. Doc. Mycol. 25 (97): 5-11.

Minter D.W. 1986. Notes of British species of Xylaria. Bulletin of the British Mycological Society 20: 91-93.

Reynders J. 1983. Xylaria oxyacanthae en X. carpophila in het Amsterdams bos. Coolia 26 (3): 60-61.

St owell E. A., Rogers J. D. 1983. Studies on Xylaria oxyacanthae. Mycotaxon 17: 433-444.

Tulasne L. R., Tulasn e C. 1863. Selecta Fungorum Carpologia. Vol. II. Paris.

Whalley A. J. S. 1987. Xylaria inhabiting fallen fruits. Agarica 8 (16): 68-72.

Whalley A. 2000. Xylaria Hill ex Schrank. (In:) L. H an se n, H. Knu d se n (eds). Nordic macromycetes. 1. Ascomycetes. Nordsvamp. Copenhagen: 249-250.

Xylaria oxyacanthae Tul. et C. Tul., gatunek nowy dla Polski

Streszczenie

Autorzy prezentują dwa stanowiska nowego dla Polski gatunku próchnilca - Xylaria oxyacanthae. Grzyb ten, rozwijający się na owocach Crataegus monogyna, został znaleziony po raz pierwszy w zadrzewieniu śródpolnym w Turwi (Wielkopolska) w roku 2001. Drugie stanowisko odkryto w Krakowie w parku miejskim w roku 2004. Materiał zielnikowy znajduje się w Stacji Badawczej ZBŚRiL PAN w Turwi i zielniku IB PAN w Krakowie. 


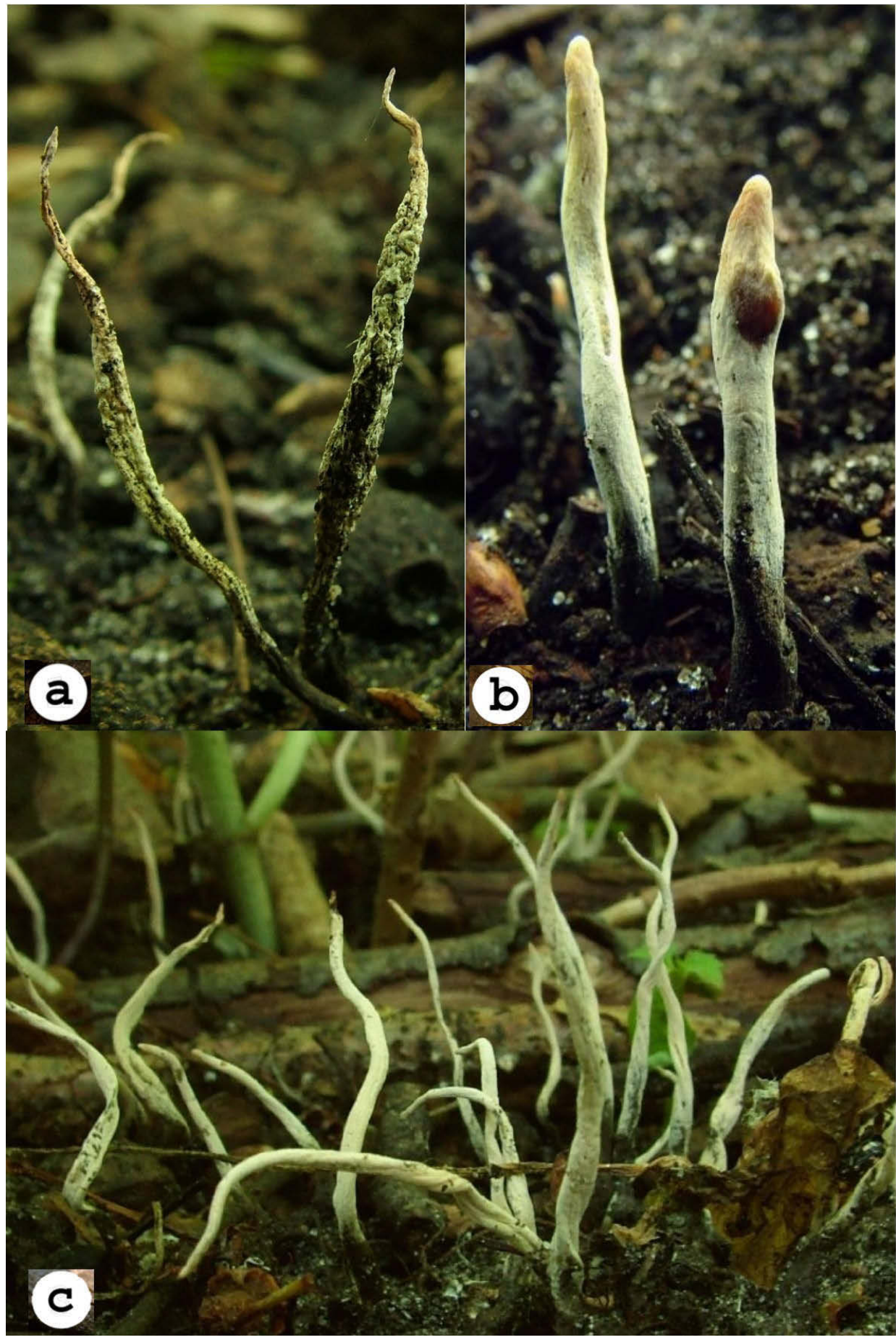

Fig. 1. Xylaria oxyacanthae - locality in Turew: a) teleomorphic stage; b) anamorphic stage; c) group of anamorphic stromata. Phot. K. Kujawa. 


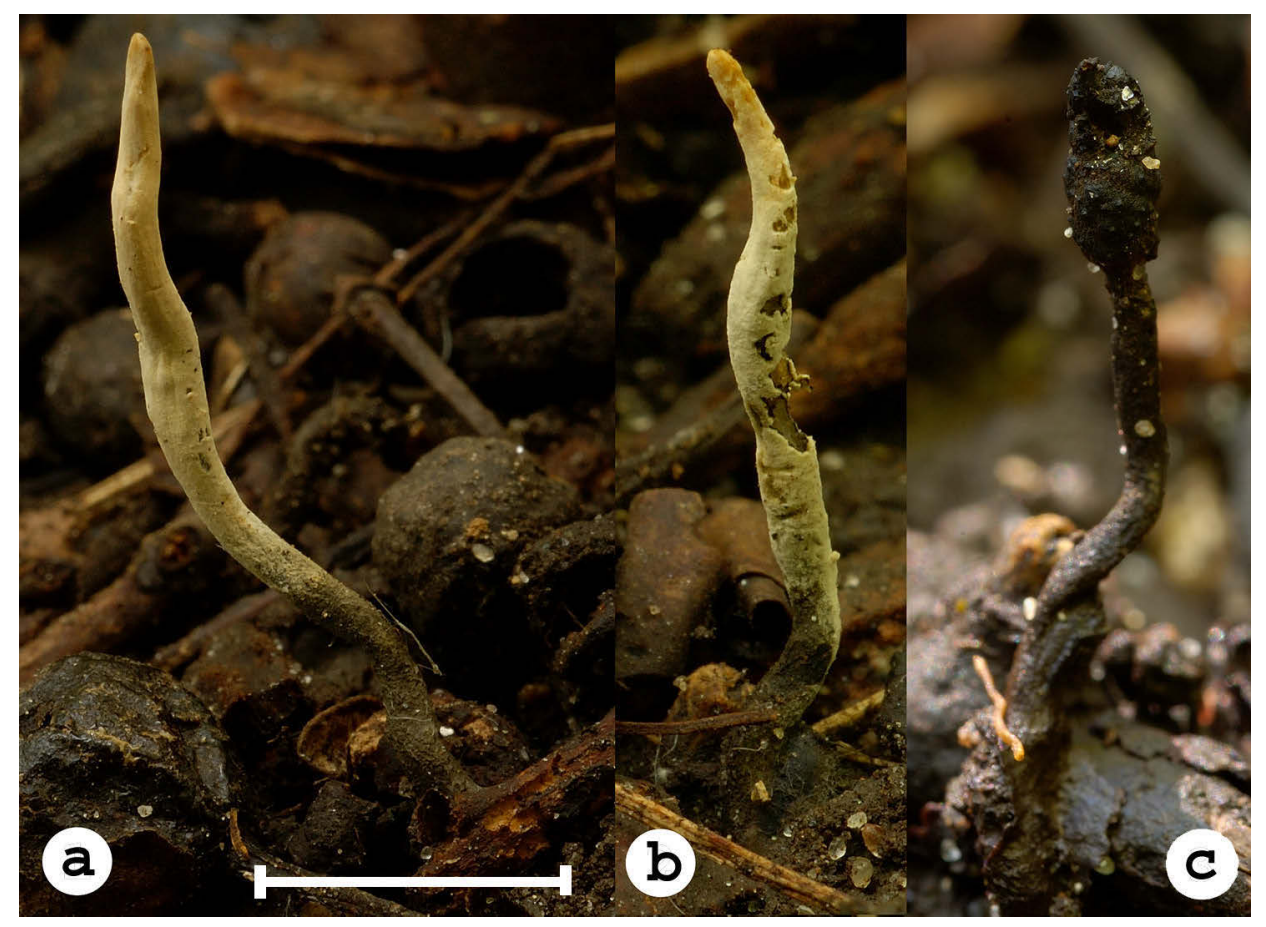

Fig. 2. Xylaria oxyacanthae - locality in Kraków: a) anamorphic stage; b) anamorfa damaged by Armadilidium vulgare; c) teleomorphic stage. Phot. D. Karasiński. 